\title{
Global Development of International Tourism and Impact on the Economy of Ukraine
}

\author{
By Olena Moskvichova ${ }^{1}$, Iryna Hryhoruk ${ }^{2}$, Yuliia Marchenko ${ }^{2}$, Yuliia Veretilnyk ${ }^{2}$
}

\begin{abstract}
The article highlights the geopolitical aspects of the international tourism development in Ukraine as a global phenomenon that carries out economic, social and international and political action. In today's world, tourism has become a powerful industry, a huge complex in which the economic and social spheres are connected. The importance of tourism in international economic activity is constantly growing, and the market itself is acquiring new trends and features, affecting trade, transport and communications, agriculture and construction. The processes of globalization in the tourism market are characterized by changes in technology, modernization of transport infrastructure, internationalization of business activity and the creation of a regulatory mechanism. The potential of world tourist flows as factors of geopolitical influence is revealed, the structure of which reflects and influences the tendencies of international interaction. The main geopolitical factors influencing the dynamics and spatial organization of international tourist flows are structured. The world market of tourist services has a clear segmentation character. The main criteria for segmentation are motivational, age and regional ones. The general tendencies of development of the international tourism, a role and a place of Ukraine in the international tourist market are characterized. It is predicted that China will become the most popular tourist country in the near future. It is determined that due to the growth of intercontinental ties, which is based on the rapid development of vehicles and, above all, jet aircraft, as well as the desire of a significant number of people to visit the most remote and exotic corners of the Earth, tourism exchange between regions will develop more intensively than within regions. However, there is a growing tendency to increase the exchange of tourists between neighboring countries under conditions of normal relations between them and between countries with related languages. The main world events that have affected tourist flows in recent years are listed: Brexit, COVID-19, military actions in Eastern Ukraine and others. The analysis of international tourist flows in Ukraine was done, in particular their dynamics and spatial structure during 2010-2019 in the context of military-political aggression by Russia and the aggravation of Ukrainian-Russian interstate relations. It is established that the current dynamics of the international tourist flow in Ukraine is characterized by a sharp decrease in international visitors, slowing down the development of tourism and reformatting the spatial structure of the incoming and outgoing tourist flow. It is also noted that among the main factors hindering the development of the Ukrainian tourism industry are the unsatisfactory state of development of infrastructure and logistics of tourism, high prices, environmental and criminal risks, low innovation activity of tourism enterprises. It is concluded that international tourism is not only a passive participant in international relations, but also an active political actor who is able to act as a channel for establishing international trust and cooperation, a factor in maintaining political stability.
\end{abstract}

Keywords: international tourism; tourist flow; international tourist arrivals; international tourism receipts

\section{Introduction}

In the context of globalization in Ukraine, tourism is recognized as a priority sector of the economy. Ukraine became a member of the World Tourism Organization. This was facilitated by the adoption at the state level of the most important normative and 
legislative acts: Resolution of the Cabinet of Ministers of Ukraine of April 29, 2002 "On approval of the State program of tourism development for 2002-2010", the Law of Ukraine of November 18, 2003 "On amendments to the Law of Ukraine "On tourism"” and the Order of the Cabinet of Ministers of June 27, 2003 "On approval of approaches for foreign and domestic tourism development". 2008 was declared the Year of Tourism by the President of Ukraine.

However, according to the most researchers in Ukraine, the available resource potential is underused, and the activities of a significant number of tourism enterprises are characterized not only by a lower level compared to tourism enterprises of economically developed countries, but also does not meet modern requirements of traditional consumers. This necessitates strengthening of public management in solving problems of modern administration, including ensuring the achievement of world-class tourism development, effective operation of tourism enterprises through the formation of a competitive tourism product that meets international standards, aimed at most effective meeting of customer's needs and increasing the profitability of tourism enterprises. After all, modern tourism is a sphere of socio-economic complex, which in many countries has become a large, rapidly developing industry. In the economy of a country it serves as a source of foreign exchange earnings and a means of employment, expands the contribution to the balance of payments, promotes economic diversification by developing tourism infrastructure, increases the attractiveness of the country as the sphere of entrepreneurship and business cooperation, and creates incentives for foreign capital into the national economy.

The development of tourism is impossible without a set of objective conditions, which include: natural-geographical, socio-economic, political, logistical, cultural, legal.

The leading place among them is occupied by the state of economic development of the country and the level of social protection of the population. It should be noted the direct relationship between economic development, national income and material well-being of the population of each country. Thus, countries with strong economies, as a rule, are leaders in the international tourism market in the number of tourist trips. The level of development of tourism infrastructure also depends on the economic condition of the state. It should be noted that the number of tourist flows is determined not only by the level of the economy in the country, but also the duration of free time; the need to restore the vitality of the population.

\section{Literature Review}

Various aspects of the development of international tourism, including in Ukraine, have been repeatedly studied in the works of domestic geographers and economists: Balabanova G.V., Gontarzhevs'ka L.I. [7], Kostina K.V. [2], Lyubitseva O.O., Mal's'ka M.P., Pobochenko L.M., Tkachenko T.I. etc. However, the understanding of tourism as a factor of international political interaction, geopolitical influence is presented only in the publications of foreign scholars. Linda Richter, a professor of political science at the University of Kansas, was one of the first to draw attention to the relevant understanding of international tourism and in many of her publications she revealed the expediency of studying the political aspects of tourism from the point of view of political science, showed 
the process of politicization of tourism development on the example of Asian countries. Different levels of the relationship between tourism and politics (from international to individual) are covered in the publications of Michael S. Hall. Recently, the political aspects of international tourism have been reflected in the collective works edited by Butler R. and Santikul V., Burns P. and Novelli M., Mufakari O. and Kelly J. The view of tourist flows as factors of geopolitical influence is revealed in detail in the works of Webster C. and Ivanov S., as well as Ignatieva I. In the context of the proposed study, the publication of Metreveli M. and Timoty D. deserves attention. The impact of the military conflict in Eastern Ukraine on the flows of inbound tourism is highlighted only in the context of assessing economic losses. Accordingly, the assessment of the spatial structure of tourist flows in Ukraine in the context of the geopolitical situation and international political influence remains an important scientific-theoretical and practical task.

Conscious Tourism's Dimension in the Historical Villages of Portugal considered Liberato P., Cerqueira I. and Liberato D. [5] in their works, this experience is interesting for implementation in Ukrainian realities.

Problems of research of tourist sphere development in Ukraine are covered in works of domestic scientists: Bezugly I. [1], Borushchak M. [4], Hryniv L.S., Gulyaeva V.G., Dolishny M.I., Kifyak V.F., Kravtsiv V.S., Milashovska O.I., Stechenko D. [1] and others. At the same time, in the works of these scientists there are almost no studies that provide a comprehensive and in-depth analysis of international tourism and its directions in general.

As noted by Karachyna N. [10, p. 112], tourism can be not only a factor of economic growth and the country's entry into the world tourism market, but also a means of comprehensive integration into the world economic space on the basis of its communicative and integration component.

Zaitseva V., considering international tourism in the context of globalization, emphasizes that globalization and regionalization are components of a single process of international tourism development, which makes it a unique economic tool capable of forming production systems of international character and retain local significance [11, p. 59].

Despite the large number of publications, in the scientific literature, both foreign and domestic, there are no studies that provide a sufficiently in-depth analysis of international tourism and characterization of current trends in its development. After all, the current state of tourism development is characterized by high growth rates; new types of tourism are emerging; new tourist routes are being developed; tourist services are being improved; new jobs are being created in this area; infrastructure is being developed; new technologies are being introduced in the field of tourism, etc.

\section{Area Under Study}

Identification of unexamined aspects of the general problem. The study of literary sources and their generalization shows the importance of this issue, and requires a more in-depth study and analysis of international experience of tourism industry.

Problem definition. The main purpose of the research is to study the state of development of international tourism in the world and its role in stimulating the economy of Ukraine, analysis of statistical indicators of tourism, global development prospects and directions 
of activation of the tourism industry in Ukraine.

\section{Results}

The growth of educational and cultural potential of society significantly increases the importance of spiritual values and broadening the horizons of tourists, strengthening their desire to learn something new.

According to experts (D. Stechenko, I. Bezugly), it is necessary, first of all, to determine the differentiation of the development strategy for each administrative district, i.e. to rank the justified development goals. This approach involves the formation of a "tree of goals". This will provide an opportunity to identify the subordination of goals at the levels of hierarchy to achieve the goal. The "tree of goals" of the strategy of ecological and economic development of the regional recreational and tourist system contains two goals:

1) development of processes of involvement of the natural environment;

2) increase in the number of visiting vacationers (Fig. 1.).

To implement the first goal, it is advisable to use four sub-goals: identification of areas with valuable health properties; increasing the area of nature reserve facilities; creation of forms of nature reserve fund, the most adapted for use in the recreational and tourist sphere; formation of natural and recreational complexes.

Achieving the second strategic goal will become a reality if the number of visitors increases and intensification of the development of recreational and tourist services (D. Stechenko, I. Bezugly).

The development of tourism is also influenced by the demographic factor, which includes the age of the population, the increase in the number of working women, trends towards later marriage and family formation, early retirement, and so on.

In the XXI century tourism has become global. Tourist flows, together with the exchange of material goods, capital, labor and information, form a network of world economic relations. In a short period of time, they have become a notable phenomenon of international life, have acquired a planetary scale.

With the deepening internationalization of the world economy, the international tourism industry has undergone significant transformations and has become an avant-garde segment of the global market. The modern tourist map of the world has changed significantly due to the growing number of countries that have integrated into the world economic and humanitarian space. According to the types of tourist services, the contingent of tourists, the intensity of tourist flows, scientists identify the following tourist markets (K. Kostina):

- traditional monopoly countries (USA, France, Spain, Italy, Great Britain, Austria);

- new regions (China, Turkey, Poland, Hungary, Czech Republic, Croatia, island countries);

- the most promising countries (Mexico, Malaysia, Thailand, Taiwan, Hong Kong);

- Applicant countries (Ukraine, Russia, Kazakhstan, Bulgaria, Romania, Saudi Arabia, UAE). 


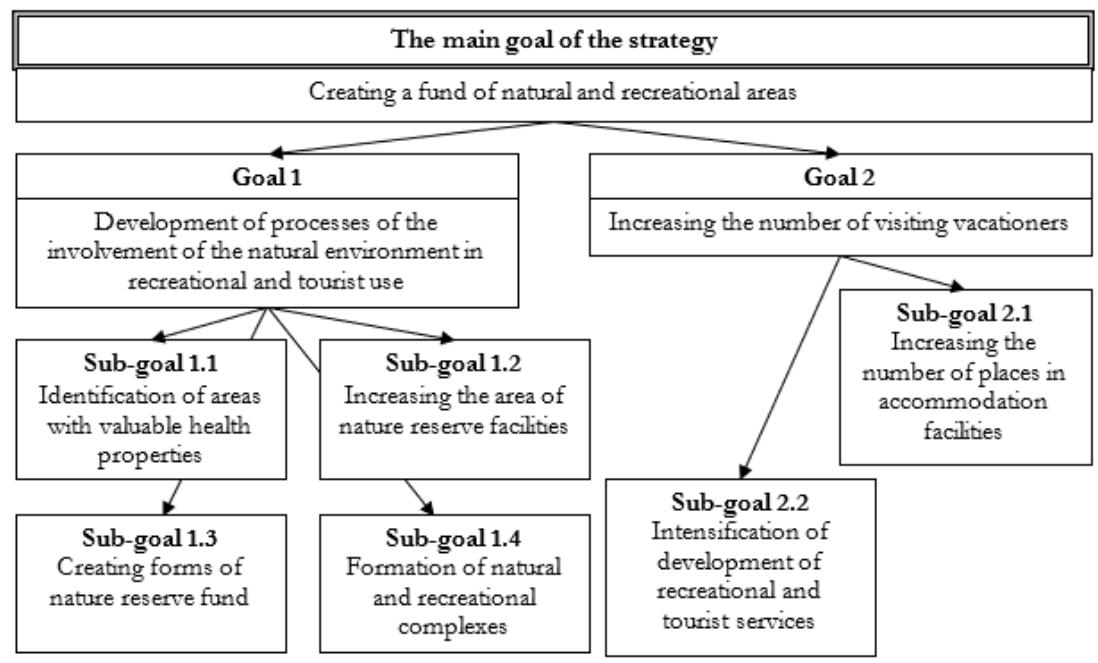

Figure 1: "Tree of goals" of strategy of ecological and economic development of the recreational and tourist system of Ukraine

Source: grouped by authors

To determine the world's leading tourist centers, first of all, two indicators are taken into account: the number of foreign tourists hosted by the country and the income from international tourism (Table 1). According to the World Tourism Organization in the XXI century there is and is projected a future tourism boom: according to the World Tourism Organization, the number of tourists traveling abroad will grow at least until 2030. With an average increase of $3.3 \%$ per year, and, according to experts, the number of tourists to a number of developing countries, including Central and Eastern European countries, will grow by $4.4 \%$ per year and in 2030 the share of tourists visiting developing countries will reach $57 \%$. At the same time, the projected revenues from tourism during the forecast period will have an average increase of $+3 \%$ per year. It should be noted that in 2019, 1.46 million international tourist arrivals were fixed and the total income from tourism was recorded in the amount of 1481 billion dollars USA. Daily tourist spending will increase to $\$ 5$ billion a day (UNWTO).

Table 1: Structure of international tourist flows and their dynamics

\begin{tabular}{|c|c|c|c|c|c|c|c|c|}
\hline \multirow[b]{2}{*}{ Country } & \multicolumn{4}{|c|}{2010} & \multicolumn{4}{|c|}{2019} \\
\hline & 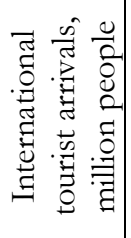 & 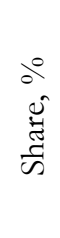 & 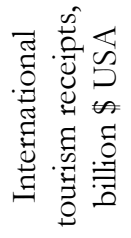 & 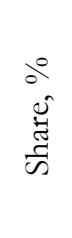 & 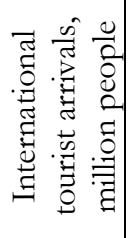 & $\begin{array}{l}\partial^{\circ} \\
\stackrel{0}{0} \\
\text { है }\end{array}$ & 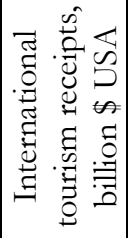 & 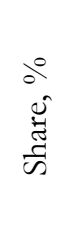 \\
\hline World & 956 & 100 & 980 & 100 & 1460 & 100 & 1481 & 100 \\
\hline France & 77,6 & 8,1 & 57,1 & 5,8 & 89,4 & 6,1 & 63,8 & 4,3 \\
\hline Spain & 52,7 & 5,5 & 58,8 & 6,0 & 83,5 & 5,7 & 79,7 & 5,4 \\
\hline USA & 60,0 & 6,3 & 137 & 14,0 & 79,3 & 5,4 & 214,1 & 14,5 \\
\hline
\end{tabular}




\begin{tabular}{|c|c|c|c|c|c|c|c|c|}
\hline \multirow[b]{2}{*}{ Country } & \multicolumn{4}{|c|}{2010} & \multicolumn{4}{|c|}{2019} \\
\hline & 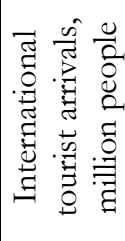 & $\begin{array}{l}00 \\
\stackrel{0}{0} \\
\text { త్ర }\end{array}$ & 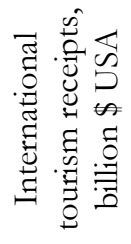 & 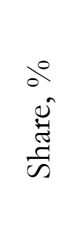 & 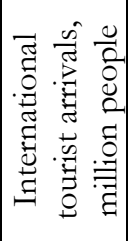 & 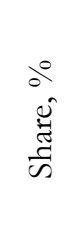 & 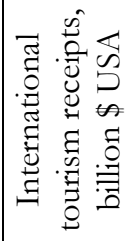 & 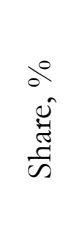 \\
\hline China & 55,7 & 5,8 & 45,8 & 4,7 & 65,7 & 4,5 & 35,8 & 2,4 \\
\hline Italy & 43,6 & 4,6 & 38,8 & 4,0 & 64,5 & 4,4 & 49,6 & 3,3 \\
\hline Mexico & 23,3 & 2,4 & 11,9 & 1,2 & 45 & 3,1 & 24,6 & 1,7 \\
\hline Thailand & 15,9 & 1,7 & 20,1 & 2,1 & 39,8 & 2,7 & 60,5 & 4,1 \\
\hline Germany & 26,9 & 2,8 & 34,7 & 3,5 & 39,6 & 2,7 & 41,6 & 2,8 \\
\hline Great Britain & 28,9 & 3,0 & 35,2 & 3,6 & 39,4 & 2,7 & 52,7 & 3,6 \\
\hline Ukraine & 21,2 & 2,2 & 3,8 & 0,4 & 13,4 & 0,9 & 1,6 & 0,1 \\
\hline Other country & 550,2 & 57,6 & 536,8 & 54,8 & 900,4 & 61,7 & 857 & 57,9 \\
\hline
\end{tabular}

Sources: grouped by authors [3].

Table 1 is based on data from 2019, so it does not show the changes in the tourism industry that were caused by the COVID-19 pandemic, the deployment of which occurred in 2020 . With the publication of the UNWTO statistical report for 2020, we can see catastrophic decline in key performance indicators of tourism industry.

Interestingly, Brexit has had little effect on the UK tourism industry. After all, its tourist flows of foreign tourists grew with the same increase as in other top tourist countries. This may have been facilitated by the fact that the United Kingdom has announced the continued admission of tourists from the European Union without visas. In addition, during 2020, the country's economy had declining trends, which made this tourist destination more attractive to tourists.

Ukraine had a negative trend in the period 2010-2019. Unstable political situation, economic crisis and, most importantly, military actions in the east of the country - were the main reasons for the decline in tourist arrivals in the country and, accordingly, led to a significant reduction in income in the tourism industry.

However, according to optimistic UNWTO forecasts, China will become the most popular tourist country in the near future. It is estimated that with an annual growth of $8 \%$, the number of tourist arrivals in China will reach 137.1 million by 2030. In 2019, Macao (China) has the largest tourism trade surplus per capita in the world. Next in popularity will be the United States (102.4 million people), followed by France, Spain, Hong Kong (UNWTO).

At the beginning of the third millennium, the ratio of intra- and interregional tourist flows in the world will change somewhat. Due to the growth of intercontinental connections, which are based on the rapid development of vehicles and, above all, jet aircraft, as well as the desire of a significant number of people to visit the most remote and exotic corners of the Earth, tourism exchange between regions will develop more intensively than within regions. However, there is a growing tendency to increase the exchange of tourists between neighboring countries under conditions of normal relations between them and between countries with related languages. 
In the Ukrainian-Polish Euroregions, the population (Poles and Ukrainians) does not feel the language barrier and this helps to strengthen tourist ties.

In today's world, tourism has become a powerful industry, a huge complex in which the economic and social spheres are connected. And even in the economies of the most industrialized countries of Western Europe and America, this industry occupies a prominent position in terms of total revenue, the number of jobs created, budget revenues. Thus, the contribution of tourism to the production of gross domestic product in the UK is $4 \%$, in the Caribbean - $20 \%$, Switzerland - $8.2 \%$ (M. Borushchak).

In large industrialized countries, a significant number of working population work in the tourism sector, in particular, in Poland - 50.4\%, in Cyprus - $72.0 \%$, in Hungary - 59.6\%, in the UK - 73.8\%, in France, respectively - 69.9\%. In developing countries, more jobs are being created in tourism than in other areas of economic activity.

The tourism industry has become if not the largest sector of the world economy, then, of course, one of the largest. This is evidenced by the fact that tourism accounts for about $12 \%$ of world gross domestic product, more than $30 \%$ of world trade services and $11 \%$ of world consumer spending, 7\% of total investment and $5 \%$ of all tax revenues. Today, every tenth employee is directly employed in the provision of tourist services, which is more than 260 million employees.

The importance of tourism in international economic activity is constantly growing, and the market itself is acquiring new trends and features, affecting trade, transport and communications, agriculture and construction.

The processes of globalization in the tourism market are characterized by changes in technology, modernization of transport infrastructure, internationalization of business activity and the creation of a regulatory mechanism.

Ukraine as an independent subject of international economic activity remains insufficiently involved in international tourism processes, although the peculiarities of geographical location, favorable climate, unique natural and recreational resources and a large number of historical and cultural monuments create opportunities for intensive development of many types of tourism.

Table 2: Relations between behavior at destination and activities carrird out at destination

\begin{tabular}{|c|c|c|c|c|c|c|c|}
\hline & & 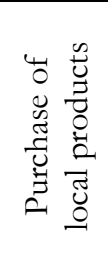 & 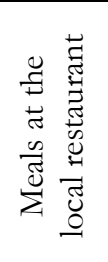 & 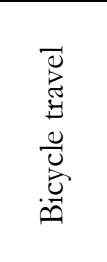 & 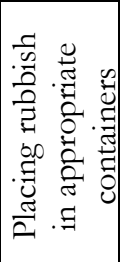 & 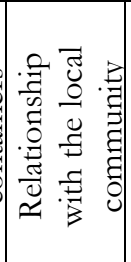 & 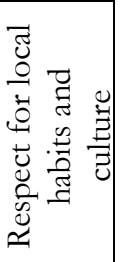 \\
\hline \multirow{2}{*}{ Visit the Historical Centre } & $\mathrm{r}$ & $0.330^{* *}$ & $0.378^{* *}$ & 0.013 & $0.323^{* *}$ & $0.247^{* *}$ & $0.411^{* *}$ \\
\hline & $\mathrm{p}$ & 0.000 & 0.000 & 0.783 & 0.000 & 0.000 & 0.000 \\
\hline \multirow{2}{*}{ Visit the main tourist attractions } & $\mathrm{r}$ & $0.234^{* *}$ & $0.345^{* *}$ & 0.004 & $0.272^{* *}$ & $0.189^{* *}$ & $0.320^{* *}$ \\
\hline & $\mathrm{p}$ & 0,000 & 0,000 & 0,929 & 0,000 & 0,000 & 0,000 \\
\hline \multirow{2}{*}{ Bicycle touring } & $\mathrm{r}$ & 0,070 & 0,029 & $0,334^{* *}$ & $-0,002$ & $0,111^{*}$ & $-0,031$ \\
\hline & $\mathrm{p}$ & 0,137 & 0,544 & 0,000 & 0,962 & 0,018 & 0,515 \\
\hline \multirow{2}{*}{ Canoeing } & $\mathrm{r}$ & $0,110^{*}$ & 0,060 & $0,314^{* *}$ & 0,045 & 0,092 & 0,016 \\
\hline & $\mathrm{p}$ & 0,019 & 0,200 & 0,000 & 0,341 & 0,052 & 0,726 \\
\hline
\end{tabular}




\begin{tabular}{|c|c|c|c|c|c|c|c|}
\hline & & 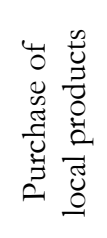 & 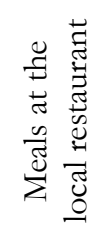 & 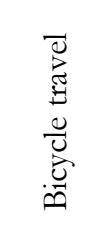 & 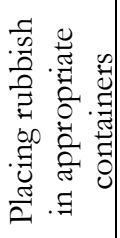 & 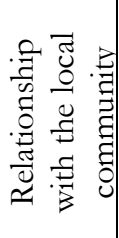 & 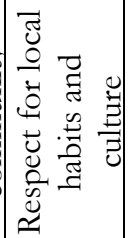 \\
\hline \multirow{2}{*}{ River beaches } & $\mathrm{r}$ & $0,159^{* *}$ & $0,170^{* *}$ & $0,167^{* *}$ & $0,107^{*}$ & $0,172^{* *}$ & $0,118^{*}$ \\
\hline & $\mathrm{p}$ & 0,001 & 0,000 & 0,000 & 0,023 & 0,000 & 0,012 \\
\hline \multirow{2}{*}{ Mountain bike routes } & $\mathrm{r}$ & 0,082 & 0,053 & $0,374^{* *}$ & 0,003 & $0,121^{* *}$ & $-0,010$ \\
\hline & $\mathrm{p}$ & 0,080 & 0,265 & 0,000 & 0,951 & 0,010 & 0,831 \\
\hline \multirow{2}{*}{ Walking trails } & $\mathrm{r}$ & $0,258^{* *}$ & $0,185^{* *}$ & $0,330^{* *}$ & $0,150^{* *}$ & $0,207^{* *}$ & $0,215^{* *}$ \\
\hline & $\mathrm{p}$ & 0,000 & 0,000 & 0,000 & 0,001 & 0,000 & 0,000 \\
\hline \multirow{2}{*}{$\begin{array}{l}\text { Involvement with the } \\
\text { local community }\end{array}$} & $\mathrm{r}$ & $0,277^{* *}$ & $0,233^{* *}$ & $0,216^{* *}$ & $0,171^{* *}$ & $0,521^{* *}$ & $0,233^{* *}$ \\
\hline & $\mathrm{p}$ & 0,000 & 0,000 & 0,000 & 0,000 & 0,000 & 0,000 \\
\hline \multirow{2}{*}{ Learning to make handicrafts } & $\mathrm{r}$ & $0,119^{*}$ & 0,038 & $0,241^{* *}$ & 0,014 & $0,227^{* *}$ & 0,034 \\
\hline & $\mathrm{p}$ & 0,011 & 0,418 & 0,000 & 0,774 & 0,000 & 0,467 \\
\hline \multirow{2}{*}{ Wildlife observation } & $\mathrm{r}$ & $0,219^{* *}$ & $0,172^{* *}$ & $0,213^{* *}$ & $0,135^{* *}$ & $0,236^{* *}$ & $0,183^{* *}$ \\
\hline & $\mathrm{p}$ & 0,000 & 0,000 & 0,000 & 0,004 & 0,000 & 0,000 \\
\hline \multirow{2}{*}{$\begin{array}{l}\text { Activities for the conservation of } \\
\text { natural resources }\end{array}$} & $\mathrm{r}$ & $0,208^{* *}$ & $0,166^{* *}$ & $0,226^{* *}$ & $0,141^{* *}$ & $0,322^{* *}$ & $0,131^{* *}$ \\
\hline & $\mathrm{p}$ & 0,000 & 0,000 & 0,000 & 0,003 & 0,000 & 0,005 \\
\hline
\end{tabular}

Source: Elaboration based on SPSS outputs ${ }^{*} p<0.05^{* *} p<0.01$ (P. Liberato, I.Cerqueira, D. Liberato)

According to table 2 the results indicate that those who carry out the listed activities most often attach greater importance to related behaviours. Moderate correlations were found between those who value activities such as visiting the historic centre, and purchase of local products, meals at local restaurant, placing rubbish in appropriate containers, relationship with the local community and respect for local habits and culture; visit the main tourist attractions and meals at the local restaurant, placing rubbish in appropriate containers, relationship with the local community, and respect for local habits and culture; also between canoeing, mountain bike routes and walking trails with bicycle travel. There is a strong correlation between those who value "Involvement with the local community" and the appreciation of the relationship with the local community as the main behaviour (P. Liberato, I. Cerqueira, D. Liberato).

Among the main factors hindering the development of the national tourism industry are the unsatisfactory state of development of infrastructure and logistics of tourism, high prices, environmental and criminal risks, low innovation activity of tourism enterprises, and recently added new problems, which have already been discussed above.

The sluggishness or lack of efficiency of the structural adjustment of any entity of the global economic system in accordance with the requirements of the new technological structure turns not only into the loss of development prospects, but also leads to complete economic degradation and innovation rate making this process fairly operational. In such circumstances, it is important to effectively and timely implement innovations in all sectors of the country's economy and manage them; for this reason, there was a "innovative management".

The most promising instruments of state policy in the long-term perspective, in addition 
to traditional measures to improve the quality of labor resources and increase investment, advocate actions to attract information and telecommunication technologies, innovations and entrepreneurial activity to the process of economic growth. To succeed in this context, countries must first of all ensure a number of prerequisites for increasing domestic R\&D expenditures, since R\&D (creation of new high-quality products based on the latest technologies) plays a leading role in providing innovative responses in post-industrial development (the desire to optimize the parameters and timing of the development of new products, as well as marketing strategies within the strategic zones of enterprise management in order to increase the long-term sweat profitability and guaranteeing competitiveness in traditional and emerging markets) (V. Bokovets).

Due to its great influence on the economic and social development of the country, the tourism industry should be regulated by the state and be closely monitored by the public. Tourism has great potential to increase employment, intensify entrepreneurship, increase production of goods and services. Thus, tourism, its industry in the context of globalization and Euroregionalization - is an intersectoral economic complex, which is an integrated system of industries, productions and activities, united by a common goal and public purpose to meet the needs of the population in leisure travel by creating and implementing tourist product. Inter-component horizontal links between enterprises of different industries involved in the organization of tourist consumption in accordance with the stages of the service process, allow to distinguish within the tourism industry functional-stage subsystems, represented by combinations of heterogeneous functionalsectoral elements performing homogeneous functions in tourism: institutional and organizational, functional and economic and territorial and economic (Table 3).

Table 3: The structure of the tourism industry

\begin{tabular}{|l|l|l|}
\hline Subsystem & Structure & Components \\
\hline $\begin{array}{l}\text { Institutional and } \\
\text { organizational }\end{array}$ & Legal & $\begin{array}{l}\text { Legislative and regulatory framework; customs } \\
\text { and consular services }\end{array}$ \\
\cline { 2 - 3 } $\begin{array}{l}\text { Funation system; insurance; financial system } \\
\text { Functional and } \\
\text { economic }\end{array}$ & End exchange rate \\
\cline { 2 - 3 } & Staff & $\begin{array}{l}\text { Training systems, research and development } \\
\text { Hotel industry; catering; service industries for } \\
\text { the provision of additional services }\end{array}$ \\
\cline { 2 - 3 } $\begin{array}{l}\text { Territorial and } \\
\text { economic }\end{array}$ & Transport & Air; automobile; railway; river; sea \\
\cline { 2 - 3 } & Tourist and health & $\begin{array}{l}\text { Tourist enterprises; tour desks; sanatoriums; } \\
\text { health facilities }\end{array}$ \\
\cline { 2 - 3 } & Socio-demographic potential & $\begin{array}{l}\text { Nature and recreation; cultural and historical; } \\
\text { man-made }\end{array}$ \\
\cline { 2 - 3 } & $\begin{array}{l}\text { Population, its ethno-religious structure, } \\
\text { traditional culture; resettlement systems }\end{array}$ \\
\hline & Economic potential & $\begin{array}{l}\text { Economic complex of the territory; } \\
\text { infrastructure systems; administrative- } \\
\text { territorial system and management system }\end{array}$ \\
\hline
\end{tabular}

Sources: developed by the authors

Prerequisite for further development of Ukrainian tourism in accordance with the trends 
of the international market of tourist services is the involvement in the international legal and regulatory framework of tourism advanced achievements of the most developed tourism industries, implementation of quality standards of tourist services, advanced technologies and methods of training of tourist staff and practices of formation of organizational and economic mechanisms of efficiency of the tourist industry functioning. Entrepreneurial aspects of international tourism include the scientific category of "world market of tourist services" as a system of commodity-money relations that arise in the process of buying and selling tourist products and involve interstate movement of consumers of services.

The formation of the world market of tourist services in its modern sense took place in the 1950s, when the development of means of transportation and income growth led to the mass of international tourist production and consumption. Current trends in the world market of tourist services are diversification, informatization of the world market of tourist services, cooperation of small and medium-sized tourist enterprises, narrowing of specialization, increasing requirements for quality of services, strengthening of state support for tourism and more.

The world market of tourist services has a clear segmentation character. The main criteria for segmentation are motivational, age and regional ones.

According to the motivational criterion, it is proposed to allocate:

- cognitive and entertaining in order to meet spiritual needs;

- recreational for treatment, rehabilitation or recreation.

According to the age:

- children and youth;

- adult;

- persons of the "third age".

According to the regional criterion - intensive counter-flows of tourist products, counterflows of tourist products with a predominance of exports, counter-flows of tourist products with a predominance of imports, unilateral export flows of tourist products (L. Gontarzhevs'ka).

An increasing role in international tourism is played by business tourism, which covers a wide range of trips. These are business trips of employees of corporations for the purpose of negotiations, participation in production meetings, presentations; trips to symposia, congresses, conferences, seminars, exhibitions; incentive trips for company employees; trips of official delegations, etc. The first group of trips is the most numerous, mainly due to the increasing integration and internationalization of economic relations in the context of global processes.

Health tourism is closely linked to the use of recreational resources. This is a holiday with mandatory preventive treatment (water and mud treatment, mineral water, etc.), outdoor recreation or an active lifestyle. One of the specific segments of health tourism is family vacation.

Hobby tourism gives you the opportunity to do your favorite thing with like-minded people on vacation or travel.

A very expensive and elite type of international tourism is adventure tourism: hiking expeditions, safari tours; circumnavigation (yachting). 
The main consumers of sports tourism are sports fans, athletes, hikers. The main task of sports tourism is to preserve opportunities to engage in the chosen sport. Among the most important requirements for sports tours should be noted the safety of tourists by hiring experienced, proven and qualified instructors; laying and constant control over the condition of the track, route, sports facilities, travel insurance.

Historically, the oldest type of international tourism is religious tourism. It includes pilgrimage (visiting holy places for worship); educational trips to get acquainted with religious monuments, religious culture; scientific trips (trips of scholars dealing with religion).

The key problem of the evolution of Ukraine's tourism industry in modern conditions is that the Ukrainian tourism business is developing with a predominant focus on the departure of citizens, while under the effective use of available natural and recreational resources, it could generate revenues of up to $\$ 4$ billion. In 2019, the number of outbound tourists compared to 2018 increased by $27.2 \%$ and amounted to 5525 thousand people, and the number of tourists entering Ukraine increased by $12.7 \%$ and amounted to only 87 thousand people; the number of domestic tourists during this period increased by $12.2 \%$ and amounted to 520 thousand people. The ratio of outbound to domestic tourists is 10:1 (State Statistics Service of Ukraine). Thus, the issue of reorientation and expansion of the number of exporters of tourist flows to Ukraine is relevant, taking into account the significant share of foreign tourists from post-Soviet and neighboring countries (Table 4).

Table 4: Ranking of the main countries of inbound tourism to Ukraine in 2019

\begin{tabular}{|l|c|c|}
\hline Country & Number of tourists, pers. & Country share, $\%$ \\
\hline Total & 14229642 & 100 \\
\hline Republic of Moldova & 4435664 & 31,2 \\
\hline Belarus & 2727645 & 19,2 \\
\hline Russian Federation & 1464764 & 10,3 \\
\hline Poland & 1144249 & 8,0 \\
\hline Hungary & 1119446 & 7,9 \\
\hline Romania & 791116 & 5,6 \\
\hline Slovakia & 366249 & 2,6 \\
\hline Turkey & 270695 & 1,9 \\
\hline Israel & 261486 & 1,8 \\
\hline Germany & 209447 & 1,5 \\
\hline USA & 153778 & 1,1 \\
\hline
\end{tabular}

Sources: compiled by the authors on the basis of data from the State Statistics Service of Ukraine

It should be noted that until 2014, there was a trend of inbound tourism to Ukraine only from post-Soviet countries. In turn, Ukrainians most often in 2019 went to Poland (999978 people), the Russian Federation (4376423 people), Hungary (3118758 people), the Republic of Moldova (1680353 people), Belarus (1186466 people), Turkey (1185057 people), Romania (1045424 people), Slovakia (854657 people), Egypt (733597 people). In the future, an important prerequisite for the qualitative evolution of the Ukrainian tourism industry is the formation of a common market for tourism services between Ukraine and the countries of Central and Eastern Europe. The creation of such a common Euro-oriented market space takes place mainly in two directions: cooperation with the 
European Union (Poland, Czech Republic, Slovakia, Lithuania, Latvia, Estonia, Hungary, and Croatia) and participation in the Black Sea Economic Cooperation (Albania, Moldova).

\section{Conclusions}

Structural re-adjustment of the Ukrainian market of tourist services should be carried out in the following areas:

- formation of effective mechanisms of state policy in the field of tourism;

- creation of a favorable investment climate in the tourist sector of Ukraine;

- development of international transport corridors on highways in tourist regions;

- introduction of a national program of inventory of material resources of the tourism industry and development of their gradual modernization;

- giving priority to cultural development;

- rural tourism, which takes into account the cultural and natural potential of Ukraine;

- development of social tourism - a system of affordable tourist services for socially vulnerable groups of people and youth;

- introduction of European standards for the provision of tourist and hotel services, training of the industry and its legislative support;

- providing advertising and information activities to create a positive image of Ukraine as a tourist center.

Especially important and promising is the development of cooperation with the EU, given the possibility of promoting the national tourism product on the European market; involvement in the information space, best practices in the organization of tourist activities; strengthening European integration processes in the country.

It should be noted that in terms of its tourist and recreational potential, Ukraine has the opportunity to become one of the largest European tourist centers.

Today, cross-border tourism business is intensifying in Ukraine, in particular within the Ukrainian-Polish Euroregions. For this purpose, the regionalization of Polish-Ukrainian cross-border corridors is taking place, which primarily contribute to the development of agricultural tourism.

\section{References}

Stechenko, D., Bezugly, I. (2010). Algoritm viznachennya strategichnih cilej rozvitku regional'noï rekreacijnoturistichnoï sistemi [Algorithm for determining the strategic goals of the regional recreational and tourist system]. Regional economy, №1, p.28-29.

Kostina, K.V. (2006). Suchasni tendencii rozvitku mizhnarodnih turistichnih rinkiv [Current trends in international tourism markets]. Bulletin of Donetsk State University of Economics and Trade, №4, p. 150 .

The World Tourism Organization (UNWTO) (2019). https://www.unwto.org/ (date of application 25.04.2021).

Borushchak, M. (2016). Problemi formuvannya strategii rozvitku turistichnih regioniv [Problems of formation of strategy of development of tourist regions]. Lviv : IRD NAS of Ukraine, p. 11. 
Liberato, P., Cerqueira, I., \& Liberato, D. (2021). Conscious Tourism's Dimension in the Historical Villages of Portugal. European Journal of Sustainable Development, \#10(1), 1. https://doi.org/10.14207/ejsd.2021.v10n1p1. (date of application 25.04.2021).

Bokovets, V., Moskvichova, O., Hryhoruk, I. \& Suprunenko, S. (2020). The ways of Improving the Innovation Management in Ukraine Using the International Development. European Journal of Sustainable Development, \#9(2), 203. https://doi.org/10.14207/ejsd.2020.v9n2p203. (date of application 25.04.2021).

Gontarzhevs'ka, L.I. (2016). Zovnishnoekonomichna diialnist turystychnykh pidpryiemstv Ukrainy [Foreign economic activity of tourist enterprises of Ukraine]. Kyiv. p. 7.

State Statistics Service of Ukraine [official site]. Access: http://www.ukrstat.gov.ua/ (date of application 25.04.2021).

Statistical Yearbook of Ukraine (2019).

Karachyna, N., Savitska, O. (2014). Rozvytok mizhnarodnoho turyzmu v Ukraini u konteksti svitovoi intehratsii [Development of international tourism in Ukraine in the context of global integration]. A young scientist, vol. 5 (08), pp. 109-113.

Zaitseva, V. and Korniienko, O. (2012). Mizhnarodnyi turyzm ta hlobalizatsiia v suchasnomu sviti [International tourism and globalization in the modern world]. Bulletin of Zaporizhia National University, vol. 2 (8), pp. 55-65. 